\title{
Experimental Transplantation of the Adenohypophysis-Primordium into the Anura Embryo
}

\author{
Toshiro Nonaka and Shin-ichi Sato \\ Section of Anatomy, Endocrinological Laboratories Gunma University
}

Introduction: The correlative differentiation of the primordia of the adeno- and neurohypophysis in the development of the amphibian has been described by P. E. S m it h, (1920). Recently, W. T. D r i s c o 11 and R.M. E a k i n, (1955), and R. M. E a k i n, (1956) performed detailed researches concerning the correlation between the differentiations of various parts of the hypophysis. However, no unequivocal explanation has been yet given. As an experiment for the elucidation of his problem, the transplantation of the adenohypophysis-primordium was undertaken. The results are given in this paper.

Materials and Methods: Embryos obtained from the same Bufo vulgaris formosus at the latter stage of development of the neurula were used. At this time, the ectoderm of the sensory layer lining the dorsal skin of the oral plate is thickened and elevated toward the wedge-shaped cavity between the prosencephalon and the dorsal wall of the foregut owing to the movement of the material from the surrounding, forming the so-called Rathke's pouch. In this thickened sensory layer, which constitutes a clearly contoured mass of cells, the primitive adenohypophysis is involved, that is an anterior part of the wedge-shaped cell aggregation develops into the primitive adenohypophysis. This part together with the whole Rathke's pouch was removed by incising a rectangular portion surrounded by the olfactory and mouth pit, with care not to injure these pits and the wall of the foregut. The removed tissue was kept in 1/2 Holtfreter solution for several hours. When it assumed a nearly spherical form it was implanted in the ventricle or subcutaneously in the ventral median line of the normal and the above mentioned ectomized embryos. The transplantation was made into the ventricle through an incision made on the anterior wall of the prosencephalon, and into the third ventricle through an incision made longitudinally on the dorsal wall along the 
precursor of the neural tube suture, carefully, to prevent the mixture of other cells with the tissue to be implanted. The ventral implantation was made as the control, in which no contact with the neural factor was made.

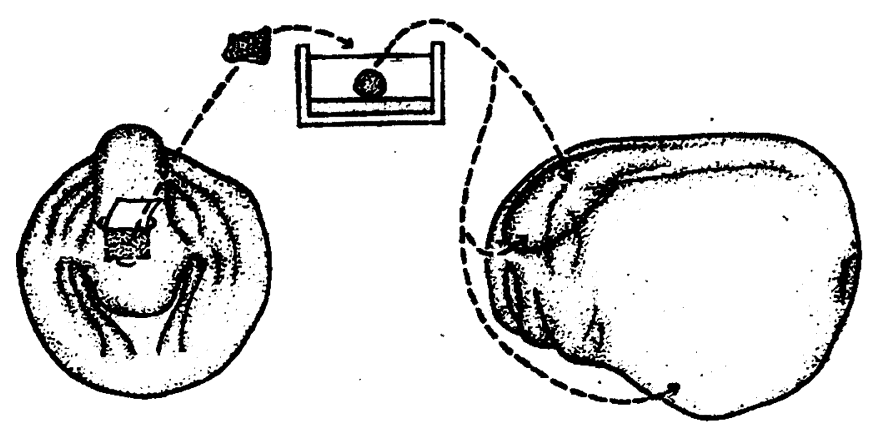

Fig. 1. Transplantation of the Adenohypophysis-primordium in a larva of Bufo vulgaris formosus. Scheme of operation.

The hosts were kept in $1 / 2$ Holtfreter solution until the operation wound cured, and then brepd in water at room temperature for about 37 days, when the control embryos began to undergo metamorphosis. At this time, for microscopical examination of the transplants placed in the test animals, the hosts were fixed in Romeis solution, embedded in paraffine, and transverse serial sectioned at $8 \mu$, and stained with Azan (Heidenhain). In total 29 samples were examined microscopically. (Fig. 1)

Findings: For several days after transplantation, no changes were observed in development. Then a slight elevation was observed on the skin of the head in some, chiefly in those in which transplantation into the third ventricle was made. Some of the elevations increased in size with the development of the embryo, turning into large projections. In hosts in which the adenohypophysis was transplanted after previous removal of it, the knee and foot joints were evidently discerned in the hind limb, the foot plate formed, which was different from the controls. This difference in development became more remarkable since the appearance of the radial toe lines. Owing to the used material, difference in the skin color was not observed conspicuously except in remarkable cases in which the dorsal skin developed a greyish blue color in contrast with the black color of the control embryos.

Microscopical observation of the samples revealed that in those in 
which an elevation or projection was produced the implanted tissue got out of the ventricle. It was located between the head skin and prosencephalon, developed, and in most cases had contact with the prosencephalon. Of the implanted tissues which remained in the ventricles, the majority in the third ventricles were divided into several parts, assumely owing to the morphogenic movement in the course of development of the host embryos. And in 6 of 25 instances (4 ventrally implanted cases excepted), the development of the hypophysis-like tissue was observed. In the following lines are given the findings in the representative instances.

Case 1: The adenohypophysis-primordium was not removed. In the morphological development there were observed no abnormalities. The degree of development was such that the gill cover was translucent making the fore limbs visible and the tail was held between the soles of the hind limbs, actively making spontaneous movement. The transplants was located in the third ventricle, involved in the mesen. chymal tissue and not divided. In had contact at several points with the diencephalon wall, and its presence checked the normal formation of pars infundibuli and considerably enlarged the third ventricle itself. The transplants appear to be pluripotent differentiation. Namely, epidermal cysts with relatively thick walls were formed in the middle, which contained in their horny structures scattered labial teeth of anuran tadpoles. On the dorsal and ventral parts of the cysts, the cartilage was differentiated, and on the right of the ventral cartilage, pars principalis of the adenohypophysis became differentiated. These were loosely envelped by connective and mesenchymal tissue without contact with the cephalic wall. But it is possible that in the early stage following plantation, the contact might have been present but was lost as a result of morphogenic movement. Under the adenohypophysis which developed from the transplants, the hypophysis of the host was observed on the infundibular wall. Viewed on the transverse section, the former was $1 / 3$ the latter, but histological observations were similar in both. There was no abnormality in the histological observation of the thyroid gland. (Fig. 2)

Case 2: The adenohypophysis of the hosts had been removed. The remarkable finding in morphological development was an upward conical projection formed on the dorsal side of the cephalic part. This was rather delayed in the growth degree compared with case 1 with respect to the hind limb. The transplanted body was found adjacent to the dorsal wall of the fore brain, constituting the content of the 
above mentioned. In this case also multiple differentiations were observed. Namely, several cartilage masses, epidermal cysts and mesenchymal tissue were produced, and further, adjacent to the dorsal wall of the ventricle, a considerable large pars principalis of the adenohypophysis was differentiated, whose dorsal part was covered with two cartilages. The pars principalis consisted of some small blood vessels and containing pigmentation. The ventral side was in contact with a ependym layer of cubic cells constituting the dorsal wall of the ventricle and with choroidal tissue on the left. Its quantitative differentiation was comparable with that of the control. Near the infundibulum of the diencephalon of the host embryo, no differentiation suggestive of pars principalis, pars intermedia and pars tuberalis was observed. But the neurohypophysis differentiated from the ventral wall of the infundibulum slightly deviated from its normal site towards the anterior, close to eminentia fasciculi optici and incontact with the basal plate of the chondrocranium. Its neural cells were arranged on the luminal surface of the infundibulum, the colloidal substance lightly staining with anilin blue and running there from toward the basement, and some pigment granules and blood cells in the cell layer suggested the vascular invasion; all displayed the normal histological observation of the neurohypophysis. Also its quantitative development was considered near normal. The development of the hosts thyroid was good, no degenerative picture such as the atrophy of the glandular part and remarkable pigmentation were observed. (Fig. 3 and 4)

Case 3: The adenohypophysis of the host had been removed. In morphological development it is similar to case 2, having a low projection on the dorsal side of the cephalic part. It was nearly equal to case 1 in the degree of development.

The transplants constituted the content of the projection. In the center there was a large epidermal cyst with a thick wall containing horny structure in the lumen, on its back side in contact with it the cartilage and connective tissue were developed, and its ventral side was close to the diencephalon wall with scattered mesenchymal cells between them. On the right of the epidermal cyst; closely attached to it, a small cell aggregation supposed to be pars principalis was observed. The thyroid was relatively well developed, having large follicles filled with colloid and flat epithelium. But these were not findings indicative of high functional sctivity.

It was also noteworthy, similar to case 2 , that solitary differentiation of the neurohypophysis was observed. Namely, the infundibular 
wall was in direct contact with the basal plate of the chondrocranium owing to the lack of pars principalis, and slightly deviated from the normal site of the neurohypophysis toward the cauda; a remarkable thickening was observed. It was filled with cells arranged on the luminal surface of the ventricle and with colloidal substance slightly staining with anilin blue and containing cellular components scattered toward the basement, and was invaded by capillaries. (Fig. 5 and 6)

Case 4: The adenohypophysis of the host had been removed. No remarkable abnormalities in morphological development were observed. As to the degree of development, the thigh was clearly distinguishable from the leg with a sunken part indicative of the knee joint between them, but the foot joint was imperfectly developed. The transplants was divided into several masses of tissues, and the differentiation of cartilage and epidermal cysts was observed. One of the masses was well differentiated in pars infundibuli of the third ventricle closely attached to its ventral right wall. A transverse section of its pars principalis showed several irregular layers of cells with a large light nuclei chiefly on the periphery, anilin blue lightly stained the colloidal substance and blood vessels filling the internal part, and here and there were scattered large and small colloidal drops staining red with azocarmin. A part of this tissue infiltrated the infundibular wall, and the other was clearly distinguished from the neural tissue constituting this wall. The colloidal drops are considered to be identical with "Sekrettropfen" of Ste nde 11, (1914). If so, this tissue, with reference to other findings, can rightly be assumed to be pars intermedia. The caudal part continuous from this tissue was partly merged with the dorsal wall of the infundibulum, and on the ventral side the cartilage was differentiated. This case completely lacked its own hypophysis, and the thyroid gland showed an atrophic picture. Similar findings were obtained in one more case. (Fig. 7)

Case 5: The adenohypophysis of the host had been removed. No remarkable abnormality in morphological development were observed. The degree of development nearly agreed with that of case 4 . The transplant was found in front of the pericardium between the ventral wall of the foregut and the skin, closer to the latter. The epidermal cyst, cartilage and horny structure were developed, but no hypophysislike tissue was visible.

The host lacked pars principalis of the adenohypophysis, and the infundibular wall which would develop into the neurohypophysis showed no thickening and adjoined to the basal plate of the chondrocranium. 
But the cells in this part were clearly distinguishable from the neighbouring ependym layer, containing some anilin blue light stained colloidal substance, small blood vessels and chromatic granules. Thus the neurohypophysis in extremely low stage of development was considered to be suggestive. (Fig. 8)

Discussion: A short historical survey of the studies on the interrelation between both primordia lobes of the hypophysis in the development is as follows: P.E. S mith, (1920) stated that the removal of the adenohypophysis-primordium retarded the development of the neurohypophysis, and the removal of the primitive infundibulum highly checked the differentiation of the adenohypophysis. W. J. A twell, (1937) transplanted the adenohypophysis-primordium near the auditory vesicle and reported that for the-differentiation of the implant, the contact with the neural tissue was required. T. U y e m a t s u, (1940) reported, as the result of experiments with Bufo, that the neurohypophysis developed despite the removal of the adenohypophysis-primordium, and that pars intermedia consisted not only of the adenohypophysis but also contained neural factor. Further, R.F. B l o u t, $(1930,1945)$, A. B. B u r ch, $(1938,1946)$, R. M. Ea k in, (1950), and W. T. D riscoll and R.M. Eakin, (1955) considered that the differentiation of pars principalis, pars intermedia and pars tuberalis also required the contact with the neural tissue, and that especially the perfect differentiation of pars intermedia depended on the contact with the infundibulum. Later, R. M. E a k in, (1956) described that when the adenohypophysis-primordium was experimentally transplanted, the inserted body closely contacting the neural tissue produced intermedin, indirectly denying the view that the contact with the infundibulum had inductive effect for the differentiation of pars intermedia. In our experiments, the transplanted sensory layer of the ectoderm containing the adenohypophysis-primordium in the latter stage of development of the neurula desplayed pluripotency regardless of the site of transplantation, differentiating cartilage, primitive cartilage, ectodermal epiermal cyst, mesenchymal tissue, horny structure, labial teeth and hypophysislike tissue. R.M. E a k i n, (1956) also noted a similar pluripotency of the transplanted adenohypophysis-primordium into the early tailbad embryo of Hyla regilla, and described the formation of the notochord, but in our experiments, the differentiation of notochord-like tissue was not observed. As to the differentiation of pars principalis of the adenohypophysis from the transplant, it occurred regardless of the previous removal of the adenohypophysis when it was located close to 
the neural tissue. That is, pars principalis differentiated whether the transplanted body was located in the ventricle, or subcutaneously on the dorsal side of the central nervous system, excepting when it was implanted subdermally into the ventral part. In some specimens the transplanted body had no contact with the neural tissue. It was supposed, and could not be more than so, that it had that contact in the early stage following the transplantation, but that it had lost it in the course of development owing to the morphogenic movement. The differentiation of pars principalis did not always require contact with the infundibular wall of the diencephalon. And the neural tissue contacted with the differentiated pars principalis of the transplant showed no trace of differentiation of the neurohypophysis. This indicates that the neural tissue have some inductive effect on the differentiation of pars principalis of the adenohypophysis, but not vice versa.

In general the identification of tissue and organ in the embryo is not always easy. However, in the adenohypophysectomized host, the development degree of the thyroid gland, or its degeneration, or the presence or absence of its atrophy give some ground to determine whether pars principalis was differentiated somewhere in the implanted body. Namly, when pars principalis was differentiated, even in the abnormal site, the thyroid gland had undergone relatively good development, and when, on the contrary, is lacked perfectly, the thyroid gland presented a degenerative picture.

It is to interest that when the transplanted tissue in the perfectly adenohypophysectomized embryo showed differentiation, the formation of the neurohypophysis on the infundibular wall seemed to be accelerated. Namely, the nearohpophysis was obviously better developed in cases with the differentiation of pars principalis than those completely lacking it, the thicking on the infundibular wall being near normal in the former.

As to the differentiation of pars intermedia, a tissue suggestive of it was observed in two cases, in both of which, a part of the transplant fell into pars infundibuli and attaching to its ventral wall, it was differentiated, and contained the so-called "Kolloidkugeln" or "Sekrettropfen" (Stendell). This supports the view of R.F. B lou nt, (1945), and A. B. B u rch, (1946) that the differentiation of pars intermedia requires contact with the infundibular wall of the diencephalon. There were no cases in which pars principalis and pars intermedia of the hypophysis were together differentiated from the transplanted tissue. At any rate, the results of the present experiment indicate the import- 
ance of pars infundibuli in the differentiation of pars intermedia and neurohypophysis.

Further, in the present experiments, the differentiation of the tissue suggestive of pars tuberalis was not observed though histological distinction of it from pars principalis at this stage of development is obsure.

Summary: From the embryos of Bufo vulgaris formosus in the latter stage of the neurula, the tissue constituting the Rathke's pouch which contains the primitive adenohypophysis was removed and implanted in the ventricle and subdermally in the ventral part of the normal and ectomized embryos of the same stage in development.

The transplant differentiated pars principalis of the adenohypophysis if it was in contact with the neural tissue, regardless of the presence or absence of the host's own adenohypophysis. The implanted adenohypophysis showed quantitatively varied developments, and exerted, in the ectomized hosts, accelerative effect on the thyroidgland. The neural tissue exerted, by contact, inductive effect on pars principalis of the adenohypophysis. But in no cases was pars tuberalis concurrently differentiated. And further, it did not appear that pars principalis differentiated from the implant induced by contact the formation of the neurohypophysis in the neural tissue.

In the ectomized host, the formation of the neurophpophysis in the infundibular wall of the diencephalon was remarkably good if the pars principalis was differentiated from the implanted tissue. Where the latter differentiation was absent, the former was retarded.

When a part of the transplanted tissue was located in the floor of the infundibulum, tissue suggestive of pars intermedia differentiated.

In the latter stage of development of neurula, the Rathke's pouch involving the primitive adenohypophysis showed pluripotency, differentiating cartilage, primitive cartilage, mesenchymal tissue, horny substance, labial teeth and ectodermal epidermal cysts.

\section{Literrture Cited}

Atwe11, W.J.: Functional transplants of the primordium of the epithelial hypophysis in Amphibia. Anat. Rec., Vol. 68 (1937)

Blount, R.F.: The interrelationship of the parts hypophysis in development. J. Exp. Zool., Vol. 100 (1945)

Burch, A.B.: An experimental study of the histological and functional differentiation of the èpithelial hypophysis in Hyla regilla. Univ. Calif. Publ. Zool. Vol. 51 (1946) 
Bedniakova, T.A.: Induktion des Infundibulums durch das Vorderende der Chorda. C.R. Acad. Sci, URSS. N.S. 15 (1937) (Berichte über die Wiss. Biol. 44).

D riscoll, W.T. and R.M. E a kin: The effects of sucrose on amphibian development with special reference to the pituitary body. J. Exp. Zool., Vol. 129 (1955)

$\mathrm{E}$ a k in, R.M.: Functional differentiation of the intermediate lobe of the amphibian pituitary dependent on nervous tissue. Anat. Rec., Vol. 117 (1953)

Eakin, R.M., and M. Harris: Function and fate of transplanted pituitary in amphibians. J. Exp. Zool., Vol. 116 (1951)

Eakin, R.M.: Differentiation of the transplanted and explanted hypophysis of the amphibian embryo. J. Exp. Zool., Vol. 131 (1956)

Etkin, W.: The developmental control of pars intermedia by brain. J. Exp. Zool., Vol. 92 (1943)

Goldberg, R.C., E. Knobil and R.O. Greep: Structure and function of hypophyseal transplants. Anat. Rec., Vol. 121 (1955)

Gaillard, P. J.: An experimental contribution to the pars intermedia of the hypophysis. Acta neerland Morph. 1. (1937) (Anat. Ber., Bd. 36)

Nonaka, T.: Experimentelle Untersuchungen über die Entwicklung der Neurohypophysis. Kaibo. Z., Vol. 30 (1955) (Japanese)

$\mathrm{S} \mathrm{m}$ it h, P.E.: The pigmentary growth and endocrine disturbances induced in the anuran tadpole by the early ablation of the pars buccalis of the hypophysis. Amer. Anat. Miemoirs., 11. (1920)

Stende11, W.: Zur vergleichenden Anatomie und Histologie der Hypophysis cerebri. Archiv für mikroskopische. Anatomie., Vol. 82 (1913)

Stende11, W.: Betrachtungen über die phylogenesis der Hypophysis cerebri nebst Bemerkungen über den Neuroporus der Chordonier. Anatomischer Anzeiger. Vol. 45 (1914)

Takasima, R. and $\mathrm{Yuba}$, S. : Ein Beitrag Zur Mīorphogenese der pars tuberalis von Hypophysis cerebri bei den verschiedenen amphibian. Folia anat. Jap. Bd. 14, H. 6 (1936)

Takasima, R. und Terato, K.: Eine kurze Mitteilung über die Entwicklung des Nervenlappens von Hypophysis cerebri bei einigen japanischen Anurenarten.

Ts ut sui, R.: Entwicklungsgeschichtliche Untersuchungen über den Hypophysenhinterlappen. Ig. Kenkyu. Bd. 11, H. 5 (1937)

Terato, K.: Embryological studies on the hypophysis in anura. Kumamoto igk. $Z$. Vol. 11 (1935) (Japaness)

U ye matsu, T.: Experimentelle Untersuchungen über die Entwicklung der Hypophyse bei Anuren. (Bufo). Folia anat. Jap. Bd. 19 (1940) 


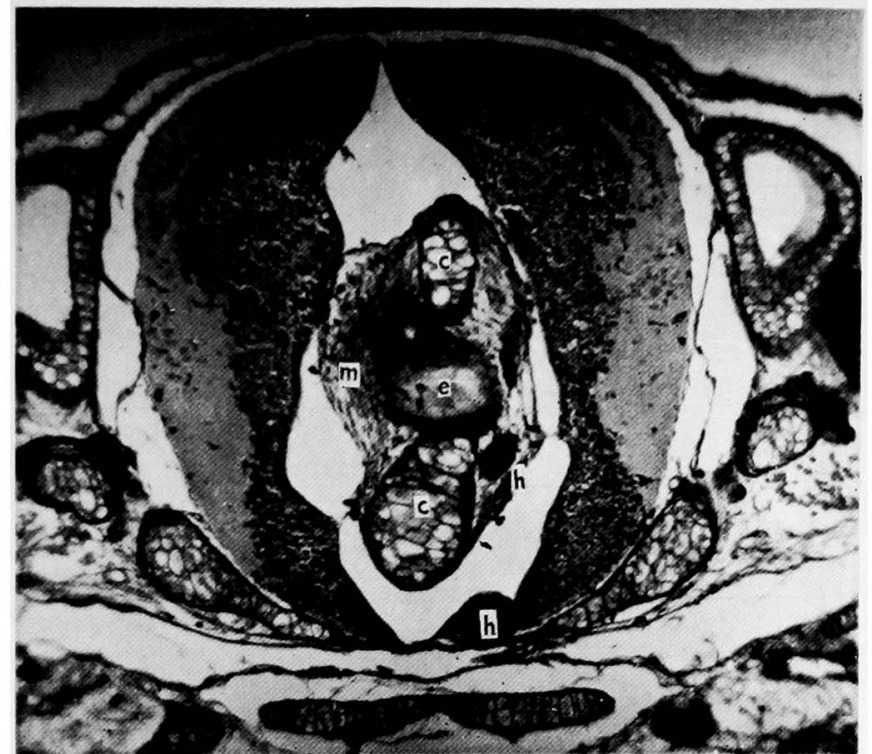

Fig. 2. Transvers section through diencephalon and infundibulum of larva. Transplant in third ventricle.

ah: adenohypodhysis c: cartilage e: epidermal cyst

$h$ : hypophysis of the host: $m$ : mesenchymal tissue

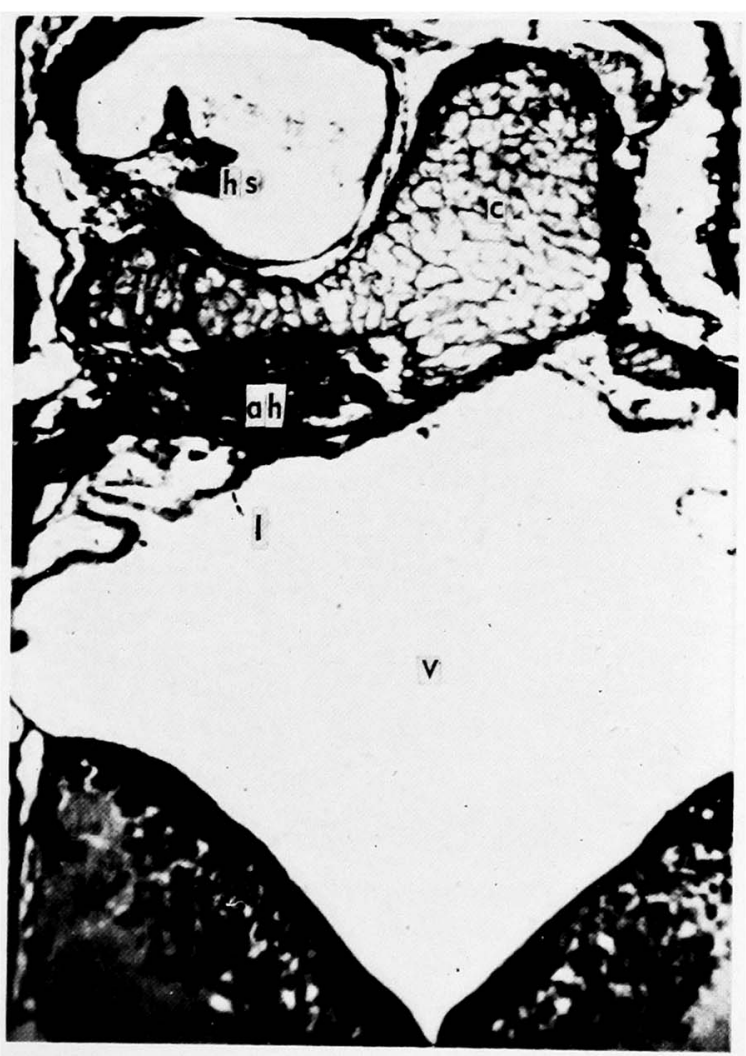

Fig. 3. Transverse section through telencephalon of adenohypophysis removed larva. Transplant is find to the dorsal wall of the fore-brain. el: ependymal layer hs: horny substance $v$ : ventricle

T. Nonaka and S. Sato 


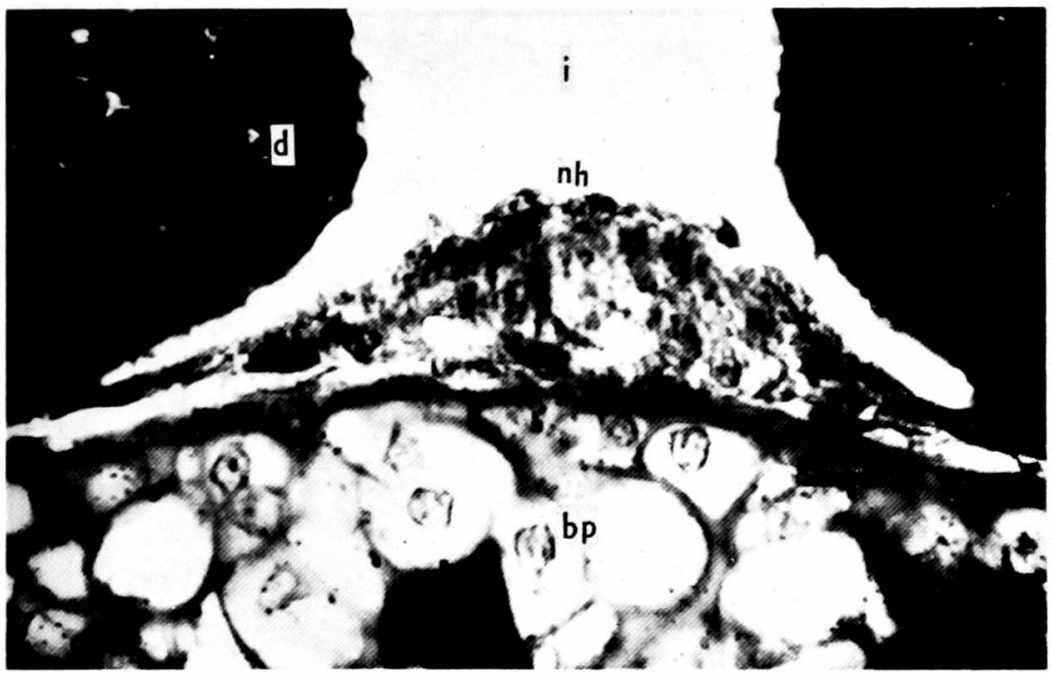

Fig. 4. Transverse section through infundibulum of larva with differentiation of the neurohypophysis alone.

bp: basal plate of the chondrocranium $d$ : wall of the diencephalon

i : infundibulum

$\mathrm{nh}$ : neurohypophysis of the host

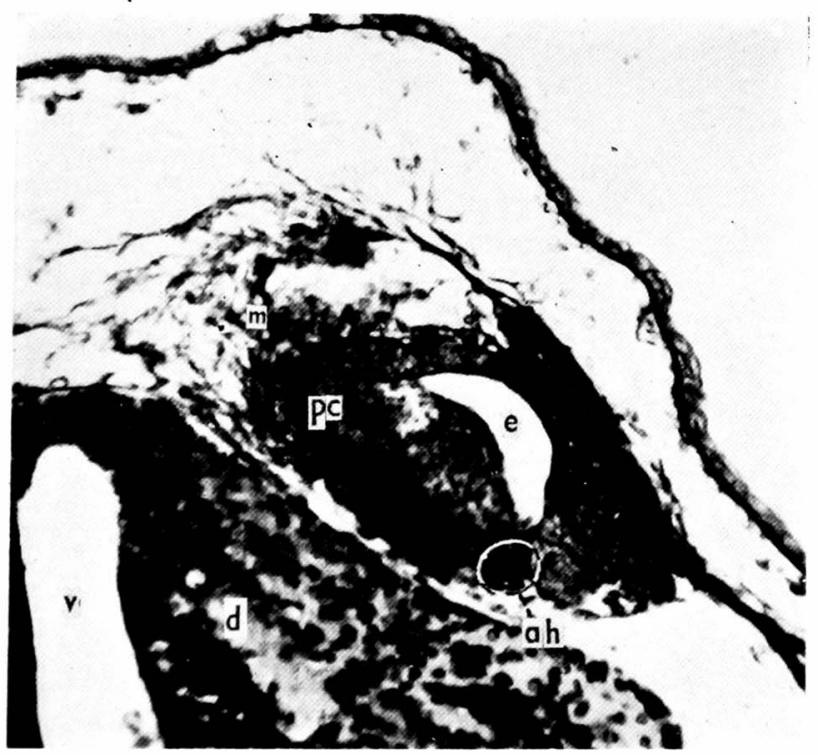

Fig. 5. Transverse section through diencephalon of adenohypophysis removed larva. Transplant is find to the dorsal right wall of the diencephalon. pc: primitive cartilage

T. Nonaka and S. Sato 


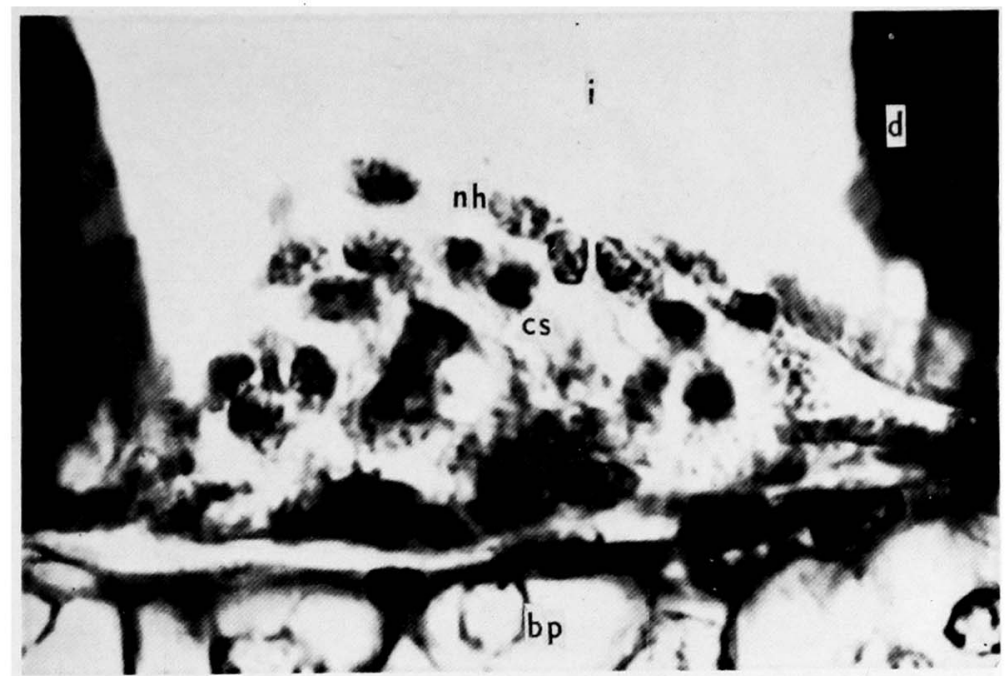

Fig. 6. Transverse section through infundibulum of larva, with differentiation of the neurohypophysis alone.

cs : colloidal substance

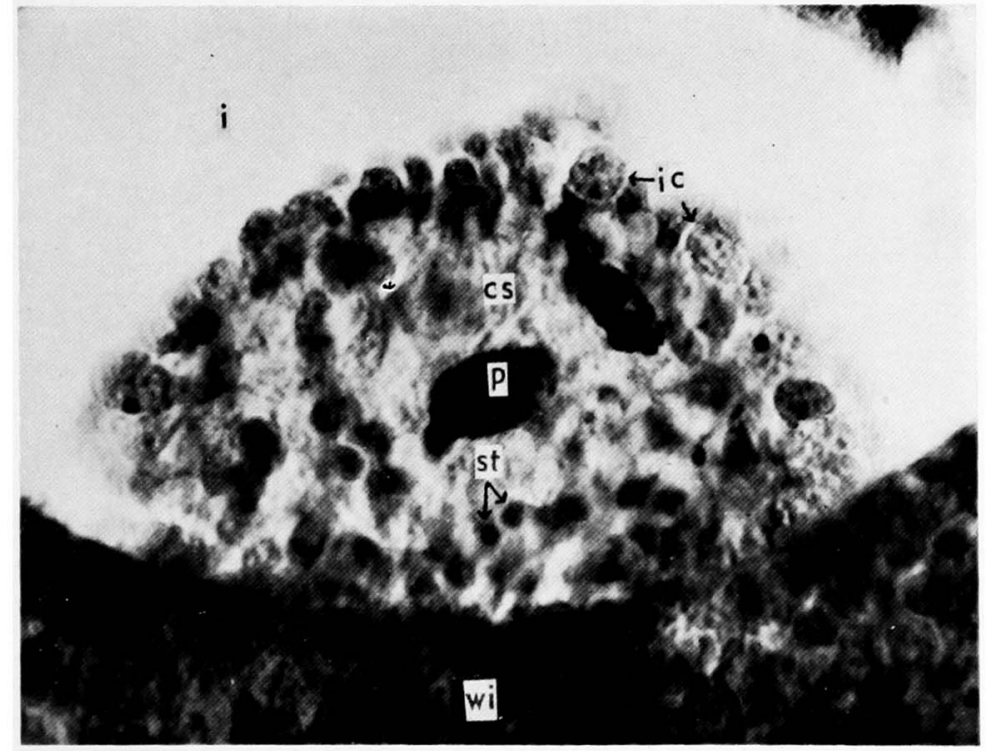

Fig. 7. Transverse seetion through infundibulum of larva. One of the masses of tissues of the transplant was in third ventricle, and attached to ventral right wall of the infundibulum.

ic: cell of the pars intermedia

p: pigmentation

st: Sekrettropfen of STENDELL wi : ventral wall of the infundibulum

T. Nonaka and S. Sato 
Plate IV

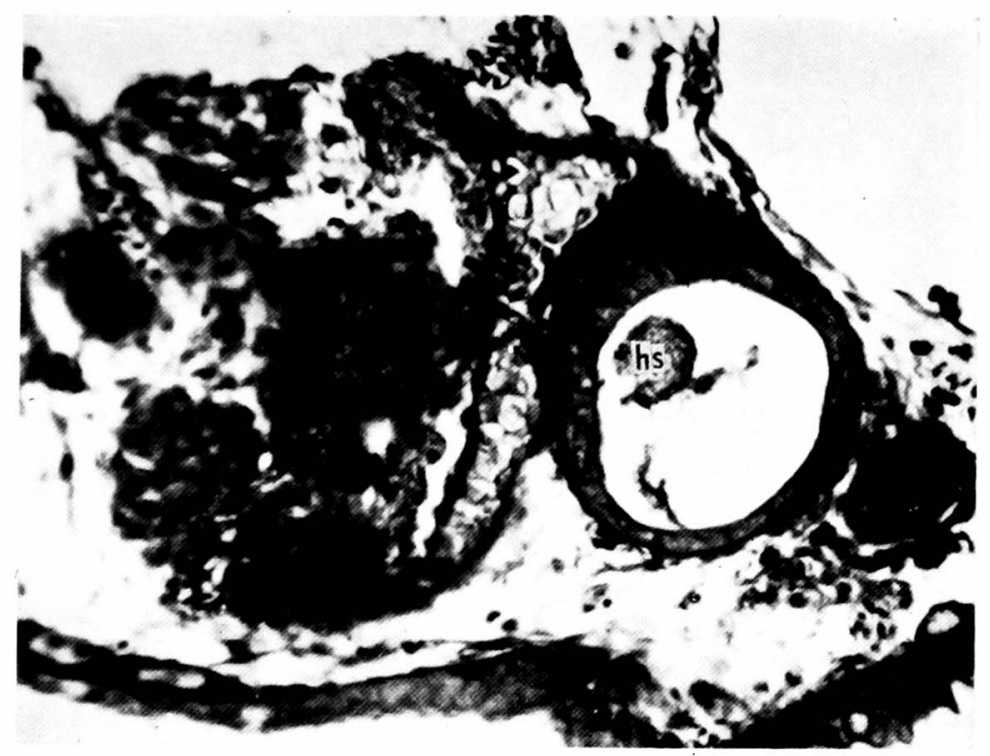

Fig, 8. Transverse section through front of the pericardium of larva. Transplant is find between the ventral wall of of the foregut and the skin. bv: blood vessel 